\title{
Matkailututkijat vihreillä alueilla
}

Ihmisen ja luonnon välisen suhteen avaaminen, analysoiminen ja ymmärtäminen matkailun sisältönä ja monitasoisina käytäntöinä luo mahdollisuuksia matkailun kestävyyden edistämiselle. Mahdollisuuksia kartoittaessamme auttaa historiallinen pitkän aikajänteen tarkastelu näkemään paitsi matkailun tilan tässä ja nyt, myös jatkumot ja sïrtymät, myönteiset ja kielteiset vaikutukset, suosion laskut ja nousut, monenkirjavat kytkennät ja merkitysten muutokset ajassa ja paikassa. Voisi ajatella, että nimenomaan luonnonperintöä, saatikka kulttuuriympäristöjen monia merkityksiä, ei voida uskottavasti käsittää ja hyödyntää kestävästi, ellemme ymmärrä niiden sisällöllistä ja ajallista kerroksellisuutta.

Luontomatkailu sellaisena kuin me sen 2000-luvulla käsitämme, on muokkautunut yli sadan vuoden takaisista vedenäärisistä aurinko- ja ilmakylvyistä, metsäseutuja ja kylämaisemia halkovista patikka- ja pyöräilyturneista, kesäisistä veneretkistä ja koskenlaskuista moniilmeisempään, abstraktimpaan ja virtuaalisempaan muotoon. Yksilötasolla luontomatkailu on nykyisin paitsi fyysistä hyvinvointia edistävää kulkemista, kiipeämistä, selviytymistä ja eloonjäämiseen liittyvää voimien ja tietotaitojen mittelyä, myös henkistä hyvinvointia lisäävää eheytymistä, herkistymistä, hiljaisuuden harjoittelua, imaginääristen tilojen tavoittelua ja spirituaalisia kokemuksia. Laajemmassa katsannossa luonto matkakohteena sisältää immateriaalisten arvojen lisäksi myös materiaalisia arvoja. Se voi olla kovaa bisnestä, luonnonresurssien hyväksikäyttöä ja kansainvälisen politiikan kiisteltyä toiminta-areenaa, mutta myös alueellisten ja kansallisten omakuvien rakennusainetta sekä toisintekemään oppimista. Vasta viime vuosina on ymmärretty, että historialliset muistinpaikat ja tilat, kulttuurihistorialliset tarinat ja kulttuurinen luonto tulevat olemaan tulevaisuuden luonto- ja kulttuurimatkailun aarreaitta. Osuvasti onkin esitetty, ettei matkailu ole joko luontoon tai kulttuuriin suuntautuvaa vaan jotain siltä väliltä - esimerkiksi suomalaisten luontokulttuureihin tutustumista ja niistä oppimista.

Luontomatkailuksi mielletään yleensä kaikki matkailutoiminnot, jotka jollain tavalla pohjautuvat tai liittyvät luontoympäristöihin. Ekomatkailu, joka yleisesti linkitetään ja usein myös rinnastetaan luontomatkailuun, tarkoittaa tiivistettynä matkailumuotoa, jossa huomioidaan matkailun taloudelliset, sosiaaliset ja ekologiset vaikutukset sekä matkailijan, ympäristön, toimialan että paikallisyhteisöjen näkökulmista. Nykymallisen luontomatkailun - ekomatkailun - juuret ovat 1960-luvun ympäristötietoisuuden läpimurrossa. Luonnon ja ihmisen välisen suhteen uudentyyppinen asemoituminen näkyi toki jo 1840-luvun kruununpuistojen toimin- 
nassa ja etenkin 1800-luvun lopun nationalistisessa maisemamatkailussa ja siitä versoneessa kansallispuistoideologiassa. Ensimmäinen suojelualue Suomessa oli Mallan tunturialue (1916), ensimmäinen luonnonsuojelulaki laadittiin vuonna 1923 ja ensimmäiset viralliset kansallispuistot perustettiin vuonna 1938. Itse ekomatkailun käsite on myöhäistä perua: se nousi alan tiedejulkaisuissa esille 1970-luvulla, ja suomalaisissa teksteissä kestävä luontomatkailu yleistyi käsitteenä vasta 1990-luvulta lähtien. Viime vuosina luontomatkailu on haluttu ymmärtää paitsi laajana temaattisena käsitteenä myös rajatumpana käsitteellisenä työkaluna, jonka avulla voitaisiin suunnata matkailutoimintojen myönteisiä vaikutuksia yhteiskuntaan ja luontoympäristöihin.

Matkailututkimus-lehden vuoden 2019 ensimmäinen numero tuo yhteen luontomatkailututkimuksen nousevia teemoja historiallisen ulottuvuuden johdattamana. Metsäntutkimuslaitoksen työraportteja -sarja ja kansalliset Luontomatkailu-symposiumit toimivat aiemmin luontomatkailua yhteen kokoavina areenoina - mutta mitä kuuluu luontomatkailun tutkimukselle nyt? Käsillä olevan teemanumeron vierailevana päätoimittajana toimii Arktisen alueen ja Suomen historian professori Maria Lähteenmäki, mikä näkyy vahvana historiantutkimuksen painotuksena. Teemanumeron artikkeleissa ja puheenvuoroissa esille nousevien lähestymistapojen perusteella voidaankin todeta suomalaisen luontomatkailututkimuksen laajentuneen eri tieteenaloille, mikä viestii yleisemminkin ihminen-luontosuhteen tulemisesta monitieteisen tutkimuksen kentälle. Kestävän kehityksen ja yhteiskunnallisen vaikuttavuuden dimensiot ovat kuitenkin yhä vahvasti läsnä monipuolistuvassakin alan tutkimuksessa.

Käsillä olevan kokoelman aloittaa historioitsija Jani Karhu, joka esittelee ja arvioi artikkelissaan kestävyysajattelun soveltamiseen liittyvää problematiikkaa kahden kansallispuistoalueen (Kolin ja UKK-puiston) tulokulmista: Ympäröivän luonnon kestävä hyödyntäminen matkailuteollisuudessa näyttää Suomessa olevan kaiken kaikkiaan vasta alkutekijöissään. Kehitystä ovat hidastaneet paikallisten toimijoiden luontoarvoihin liittyvät ristiriitaisuudet, yhteistoiminnalliseen kulttuuriin liittyvän tietotaidon puutteet ja hallinnollinen säätely. Uusia toimintamahdollisuuksia luontomatkailuyrityksille koetaan löytyvän paikallisesta historia- ja kulttuuritarjonnasta sekä erityisistä luontokohteista, kuten monimuotoisilta järviseuduilta. Historioitsija Oona Ilmolahti pureutuu artikkelissaan pohjoiskarjalaisesta näkökulmasta kulttuuriselle luonnonympäristölle annettuihin merkityksiin ja historiakuvan hyödyntämiseen alueen matkailussa. Hänen aiheensa viitekehyksenä on viimeaikaisen kansainvälisen ympäristöhistoriallisesti orientoituneen tutkimuksen pyrkimys kyseenalaistaa ja purkaa keinotekoisena pidetty raja ihmisen historian ja luonnon historian välillä. Kirjoittajan mukaan matkailua varten sanallistettu ja merkitty kulttuurinen luonto on luontomuseo, joka voimistaa paikallisia historiakuvia. Historiantutkimuksen lähestymistapoja soveltaa myös venäläinen tutkija Alexander Osipov, joka avaa orastavaa ja niukasti tutkittua Venäjän Karjalan ekoturismia, sen kehitystä ja mahdollisuuksia seudun kansallispuistokeskustelun viitekehyksessä. Kirjoittaja osoittaa konkreettisesti muutosprosessin ja käännekohdat neuvostomallisesta luontopolitiikasta nyky-Venäjän ympäristöpolitiikan linjauksiin ja niihin sisältyviin luontomatkailun tulevaisuuden näkymiin.

Kauppatieteilijät Juulia Räikkönen ja Miia Grénman sekä luonnontieteilijät Henna Rouhiainen ja Ilari E. Sääksjärvi tuovat katsauksessaan luontomatkailututkimuksen piiriin yliopis- 
tojen omat käytänteet ja rohkaisevat tutkijoita pohtimaan aktiivisemmin omaa rooliaan ja kykyään saada matkailijat arvioimaan toimintansa vastuullisuutta. Kirjoittajat peräänkuuluttavat tutkimuksia, joissa tiedematkailun ja kestävän kehityksen välisiä kytköksiä sekä tieteen roolia pohdittaisiin eri näkökulmista, ehkä nykyisiä käytäntöjä haastaenkin.

Teemanumeron puheenvuorot laajentavat niin ikään luontomatkailututkimuksen kenttää akustiikan analyysiin (matkailututkijat Ivan Fesenko ja José-Carlos García-Rosell) sekä lasten ja nuorten luontosuhteiden tarkasteluun (matkailututkija Outi Rantala ja ympäristötieteiden tutkija Riikka Puhakka). Teemanumeron päättää Matkailututkimus-lehdessä ensimmäistä kertaa julkaistava tutkijahaastattelu. Matkailumaantieteen väitöskirjatutkija Sini Kantolan haastattelemana matkailu- ja virkistystutkimuksen professori ja johtaja Norma Nickerson Montanan yliopistosta pohtii luontomatkailun haasteita, kuten matkailun kasvun hallitsemista, jakamistalouden ilmiöitä sekä ilmastonmuutoksen vaikutuksia - eli aiheita, jotka ovat erittäin ajankohtaisia myös Suomessa.

Rovaniemellä ja Helsingissä

19.6.2019

Outi Rantala

Päätoimittaja
Maria Lähteenmäki

Vieraileva päätoimittaja 